\title{
IMPLEMENTASI KONSEP MADRASAH BERWAWASAN LINGKUNGAN (Studi Kasus di MAN Purworejo)
}

\author{
Nur Chamidah \\ (SMP N 1 Purworejo) \\ nurchamidah234@gmail.com
}

\begin{abstract}
ABSTRAK
Penelitian ini bertujuan untuk mendeskripsikan Sekolah Adiwiyata di MAN Purworejo yang mencakup 4 komponen program Adiwiyata, yaitu Kebijakan berwawasan lingkungan, Pelaksanaan Kurikulum Berbasis Lingkungan, Kegiatan Lingkungan Berbasis Partisipatif dan Pengelolaan Sarana Pendukung Ramah Lingkungan. Penelitian ini merupakan penelitian kualitatif dengan pendekatan deskriptif. Informa penelitian ini adalah Tim Adiwiyata Sekolah, Kepala Sekolah, Wakil Kepala Sekolah Bidang Sarana dan Prasarana, Humas Sekolah, Guru, Karyawan dan Siswa. Lokasi penelitian di MAN Purworejo Teknik pengumpulan data dengan triangulasi melalui wawancara, observasi, dan studi dokumentasi. Hasil penelitian menunjukkan bahwa: (1) pelaksanaan kebijakan berwawasan lingkungan sudah terlaksana dengan merubah visi misi yang mendukung pengelolaan lingkungan dan adanya alokasi dana untuk program Adiwiyata dalam upaya perlindungan dan pengelolaan lingkungan sekolah, kurikulum berwawasan lingkungan dilaksanakan dengan mengintegrasikan materi wawasan lingkungan ke dalam mata pelajaran, kegiatan lingkungan bersifat partisipasif dilaksanakan melalui berbagai aksi lingkungan baik yang diselenggarakan dari sekolah maupun instansi dan mengelola sarana ramah lingkungan dengan memanfaatkan Green House, ruang terbuka hijau dan halaman sekolah untuk pembelajaran. (2) Sekolah telah mengupayakan beberapa kegiatan yang melibatkan peserta didik dalam program Adiwiyata, antara lain melibatkan siswa dalam aksi lingkungan, dan workshop lingkungan hidup dan pelatihan daur ulang limbah. Kendala yang dihadapi adalah kurangnya kerjasama dan kurangnya kesadaran para siswa terhadap kepedulian madrasah.
\end{abstract}

Kata Kunci: Sekolah Adiwiyata, Peningkatan Mutu Sekolah.

\section{PENDAHULUAN}

Manusia dan lingkungan hidup memiliki hubungan ketergantungan yang erat kaitannya. Segala sesuatu yang disediakan oleh lingkungan dapat dimanfaatkan manusia seoptimal mungkin untuk memenuhi kebutuhannya. Lingkungan hidup mempengaruhi sikap dan perilaku manusia, begitu pula manusia akan mempengaruhi lingkungan hidupnya. Faktor lingkungan seperti tanah, iklim, dan sumber daya alam dapat menjadi pra kondisi bagi sifat dan perilaku manusia, sedangkan manusia juga memiliki pengaruh dalam hal menjaga kelestarian lingkungan hidupnya. 
Peran manusia terhadap lingkungan hidup dapat dikategorikan menjadi dua, yaitu peranan positif dan peranan negatf. Peran positif disini maksudnya kegiatan yang dilakukan manusia menguntungkan bagi lingkungan hidupnya, seperti mengadakan reboisasi, melakukan daur ulang, dan lain sebagainya. Sebaliknya, manusia juga bisa memiliki peran negatif bagi lingkungan, artinya merugikan lingkungan hidup seperti, melakukan eksploitasi sumber daya alam, melakukan pembuangan limbah secara semena-mena, dan lain sebagainya. Akibatnya, lingkungan hidup juga akan merespon sesuai dengan aksi yang diterimanya. Ketika manusia memperlakukan lingkungan hidup dengan kurang baik, maka lingkungan hidup juga akan merespon dengan tidak baik. Misalnya ketika manusia melakukan penebangan liar, maka lingkungan hidup akan merespon dengan tidak melakukan penyerapan air secara maksimal dan menyebabkan bencana banjir. Selain bencana banjir merupakan akibat proses alami yang terkait dengan ulah manusia baik secara langsung (seperti kekeringan dan tanah longsor) maupun yang tidak langsung (seperti banjir pasang akibat penurunan permukaan tanah daerah pantai). Akibat yang ditanggung dari bencana alam tersebut selain mengalami kerugian material juga menciptakan suatu kondisi krisis lingkungan.

Fenomena kerusakan lingkungan sudah dituliskan Allah dalam Al Qur'an Surat Ar-Rum ayat 41:

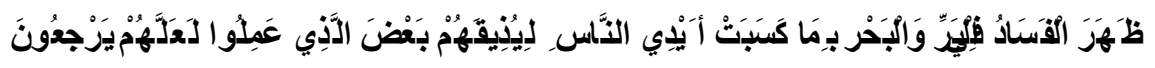

Telah nampak kerusakan di darat dan di laut disebabkan karena perbuatan tangan manusia, supaya Allah merasakan kepada mereka sebagian dari (akibat) perbuatan mereka, agar mereka kembali (ke jalan yang benar).

Kerusakan lingkungan hidup di Indonesia semakin hari semakin parah. Kondisi tersebut secara langsung telah mengancam kehidupan manusia. Tingkat kerusakan alam pun meningkatkan resiko bencana alam. Kondisi krisis lingkungan sendiri sebenarnya muncul karena kelalaian manusia itu sendiri. Kegiatan manusia dengan mengeksploitasi sumber daya yang disediakan lingkungan untuk menjadi bekal akan kebutuhan manusia mungkin masih dianggap suatu kewajaran demi menjaga kelangsungan hidup. Namun tindakan tersebut dinilai menjadi salah apabila kebutuhannya tidak pernah tercukupi dan memperlakukan alam berdasarkan keinginan sendiri. Hal ini tentunya akan mengganggu keseimbangan alam. 
Dalam Peraturan Menteri Negara Lingkungan Hidup Republik Indonesia Nomor 15 Tahun 2012 tentang Panduan Valuasi Ekonomi Ekosistem Hutan dijelaskan beberapa dampak negatif dari kerusakan hutan dan penebangan liar antara lain:

1. Kehilangan produk kayu dan non kayu

2. Erosi tanah

3. Kehilangan unsur hara tanah

4. Penimbunan tanah di bagian hilir

5. Pengurangan kesuburan tanah

6. Penurunan produktifitas pertanian, perikanan, transportasi dan atau

7. Kehilangan air karena tingkat larian air yang tinggi.

Dapat dilihat bahwa dampak tersebut berjangka panjang dan belum merupakan dampak secara keseluruhan dari hutan yang hilang. Dampak langsung yang dirasakan dari kebakaran hutan antara lain terkontaminasinya oksigen sehingga menurunkan kualitas udara yang dapat mengganggu aktivitas sehari hari

Peran lingkungan bagi manusia merupakan unsur yang sangat penting dalam menunjang kehidupan. Hal ini dikarenakan lingkungan tidak hanya berperan sebagai tempat beraktivitas manusia. Dalam lingkungan segala kebutuhan manusia sudah tersedia sehingga terdapat upaya untuk mengeksploitasi lingkungannya sendiri demi lingkungan hidup. Dengan adanya interaksi ini maka dapat dipastikan bahwa kondisi lingkungan juga dipengaruhi oleh perilaku manusia.

Berdasarkan hubungan manusia dengan lingkungan hidup di atas, maka dibutuhkan sebuah pengelolaan dan pemeliharaan kelestarian lingkungan. Salah satu jalan keluarnya adalah dengan melakukan sosialisasi lingkungan hidup dan alam melalui pendidikan lingkungan. Pengetahuan tentang lingkungan akan membuat para siswa mengerti tentang permasalahan, perlindungan dan pengelolaan lingkungan baik lingkungan hidup biotic maupun non biotic.

Penyelesaian masalah di sekolah melalui berbagai bidang dapat dilakukan dengan berbagai cara yang dirasa bisa membantu mewujudkan cita cita untuk menjadi sekolah yang baik. Salah satunya dalam bidang penanaman nilai nilai cinta alam, sekolah bisa mengikuti program sekolah adiwiyata. Dengan melaksanakan program Adiwiyata akan menciptakan warga sekolah khususnya peserta didik yang berbudaya lingkungan, sekaligus mendukung dan mewujudkan sumber daya manusia yang

\footnotetext{
${ }^{1}$ Peraturan Menteri Negara Lingkungan Hidup Republik Indonesia Nomor 15 Tahun 2012 tentang Panduan Valuasi Ekonomi Ekosistem Hutan.
} 
memiliki karakter bangsa terhadap perkembangan ekonomi, social dan lingkungannya dalam mencapai pembangunan berkelanjutan di daerah.

Menurut Undang Undang RI No 32 tahun 2009 pasal 1 ayat 2 tentang Perlindungan dan Pengeloaan Lingkungan Hidup (PPLH) adalah upaya sistematis yang terpadu yang dilakukan untuk melestarikan fungsi lingkungan hidup dan mencegah terjadinya pencemaran dan/atau kerusakan lingkungan hidup yang meliputi perencanaan, pemanfaatan, pengendalian, pemeliharaan, pengawasan dan penegakan hukum. $^{2}$ Seperti yang sudah dijelaskan dalam Undang Undang di atas bahwa lingkungan hidup membutuhkan pelestarian agar terhindar dari segala permasalahan lingkungan hidup. Menurut Syukri Hamzah, pengelolaan lingkungan yang dilakukan dapat dikatakan efektif tergantung dari upaya mengadopsi etika yang baik dalam berperilaku. ${ }^{3}$ Perilaku yang dimaksud adalah perilaku yang ramah dan peduli dengan keadaan lingkungan

Melihat persoalan pengelolaan lingkungan tersebut pemerintah berkomitmen dalam menjaga lingkungan dari kerusakan melalui pendidikan. Untuk mendukung Perlindungan dan Pengelolaan Lingkungan hidup di madrasah, maka Kementerian Lingkungan Hidup bekerja sama dengan Kementerian Pendidikan dan Kebudayaan untuk mengembangkan program pengelolaan lingkungan yang disebut program Adiwiyata. Tujuan dari Program Adiwiyata adalah mewujudkan warga madrasah yang bertanggungjawab dalam upaya perlindungan dan pengelolann lingkungan hidup melalui tata kelola madrasah yang baik untuk mendukung pembangunan berkelanjutan. Keuntungan dalam mengimplementasikan program Adiwiyata bagi madrasah adalah madrasah dapat menciptakan tempat pembelajaran tentang nilai nilai pemeliharaan lingkungan dan pengelolaan lingkungan hidup dengan upaya meningkatkan petlindungan dan pengelolaan lingkungan melalui kegiatan pengendalian pencemaran, pengendalian kerusakan dan pelestarian fungsi lingkungan hidup sehingga tercipta kondisi belajar mengajar yang lebih kondusif untuk siswa. Sementara manfaat program Adiwiyata bagi siswa adalah menumbuhkan kepedulian terhadap lingkungan dan

\footnotetext{
${ }^{2}$ Undang Undang Republik Indonesia Nomor 32 Tahun 2009 tentang Perlindungan dan Pengeloaan Lingkungan Hidup (PPLH).

${ }^{3}$ Hamzah, Syukri Hamzah. Pendidikan Lingkungan: Sekelumit Wawasan Pengantar. (Bandung: Refika Aditama, 2013), hlm. 14.
} 
memahami betapa pentingnya memelihara lingkungan yang baik, terutama lingkungan pendidikan.

Pendidikan memiliki peranan yang penting dalam membentuk karakter sebuah bangsa. Manajemen pendidikan karakter di madrasah harus dilaksanakan oleh segenap komponen madrasah, masyarakat, pemerintah dan para stake holders pendidikan. Oleh sebab itu, madrasah sebagai sarana pendidikan perlu memberikan pengetahuan yang cukup kepada siswanya mengenai lingkungan hidup dan alam. Hal ini selaras dengan tujuan pendidikan nasional seperti yang tertulis dalam UU RI No. 20 Tahun 2003 tentang Sisdiknas, yaitu untuk mengembangkan kemampuan dan membentuk watak serta peradaban bangsa yang bermartabat dalam rangka mencerdaskan kehidupan bangsa, bertujuan untuk berkembangnya potensi peserta didik agar menjadi manusia yang beriman dan bertakwa kepada Tuhan Yang Maha Esa, berakhlak mulia, sehat, berilmu, cakap, kreatif, mandiri, dan menjadi warga Negara yang demokratis serta bertanggung jawab. ${ }^{4}$

Salah satu usaha yang dilakukan madrasah untuk ikut serta dalam usaha melestarikan lingkungan adalah dengan menerapkan program madrasah adiwiyata. Program ini diharapkan dapat menjadi tempat pembelajaran bagi seluruh warga madrasah kaitannya dengan upaya penyelamatan lingkungan dan pembangunan berkelanjutan.

Dalam lembaga pendidikan, semua unsur pelaksanaan pendidikan akan berjalan dengan baik jika dikelola dengan konsep dan prinsip manajemen. Konsep dan prinsip manajemen yang diterapkan dengan baik dan benar berdampak pada efektifitas pelaksanaan program, meningkatkan kualitas, dan produktifitas pendidikan yang pada akhirnya akan menjadikan lembaga pendidikan tersebut menjadi bermutu

Menurut Gaffar, mutu pendidikan sebagai salah satu indikator untuk melihat produktivitas dan erat hubungannya dengan masalahbpengelolaan atau manajemen pada lembaga atau madrasah. ${ }^{5}$ Hal ini dapat dikaitkan dengan pernyataan kegagalan mutu dalam suatu organisasi disebabkan oleh kelemahan manajemen.

\footnotetext{
${ }^{4}$ Undang-undang Republik Indonesia Nomor 20 Tahun 2003 tentang Sistem Pendidikan Nasional.

${ }^{5}$ Rohiat. Manajemen Sekolah: Teori Dasar dan Praktik, Dilengkapi dengan Contoh Rencana Strategis dan Rencana Operasional. (Bandung: Refika Aditama, 2008), hlm.19.
} 
Mutu dalam pendidikan bukanlah merupakan barang, akan tetapi merupakan layanan, di mana mutu harus dapat memenuhi kebutuhan, harapan, dan keingiinan semua pihak/pemakai dengan focus utamanya terletak pada peserta didik. Mutu pendidikan berkembang seirama dengan tuntutan kebutuhan hasil penddidikan yang berkaitan dengan kemajuan ilmu dan tekhnologi yang melekat pada wujud pengembangan kualitas sumber daya manusia. Sejalan dengan hal tersebut, maka dalam pengelolaan madrasah yang efektif dan berorientasi pada mutu pendidikan memerlukan suatu komitmen yang penuh dengan kesungguhan dalam peningkatan mutu.Komitmen tersebut harus didukung oleh dedikasi yang tinggi terhadap mutu melalui proses yang berkelanjutan oleh semua pihak yang terlibat.

Mutu pendidikan berkaitan dengan tercapai atau tidaknya tujuan pendidikan nasional seperti yang tercantum di dalam UU No. 20 Tahun 2003 tentang sistem pendidikan nasional. Selain itu, mutu pendidikan dapat dikatakan baik apabila memenuhi standar nasional pendidikan. Terpenuhinya standar minimal pendidikan yang merupakan standar nasional pendidikan merupakan prasyarat untuk meningkatkan mutu pendidikan termasuk madrasah. Sejak lahirnya UU No. 20 Tahun 2003 tentang Sistem Pendidikan Nasional tersebut yang diikuti oleh PP No. 19 Tahun 2005 tentang standar Nasional Pendidikan, madrasah memiliki kedudukan yang sama dengan madrasah umum. Oleh karena itu, peningkatan mutu madrasah harus dilaksanakan seiring dengan undang-undang dan peraturan pemerintah tersebut. Hal ini karena kiprah madrasah sangat besar telah memberikan kontribusi dalam pendidikan nasional dalam pendidikan nasional Indonesia. Ia tetap eksis di tengah keterbatasan dan turut berpartisipasi dalam mencerdaskan kehidupan bangsa.

Mutu pendidikan merupakan masalah pokok yang akan menjamin perkembangan madrasah dalam meraih status di tengah tengah persaingan dunia pendidikan yang kian keras. Menemukan sumber mutu adalah sebuah petualangan yang sangat penting. Pelaku pelaku dunia pendidikan menyadari keharusan mereka untuk meraih mutu tersebut dan menyampaikannya pada pelajar dan anak didik. Mutu menjadi sesuatu yang sangat penting karena berkaitan dengan kualitas produk atau lulusan lembaga pendidikan formal maupun normal yang mampu berkompetisi sesuai tuntutan dunia. Mutu pendidikan atau mutu madrasah tertuju pada mutu lulusan yang berasal dari madrasah tersebut. Supaya menghasilkan lulusan yang bermutu maka proses pendidikan 
harus bermutu juga. Produk mutu setiap lembaga pendidikan harus mampu berkiprah di dunia usaha dan mampu menghasilkan keuntungan sebesar besarnya bagi keluarga, masyarakat, bangsa dan Negara.

Mutu pendidikan akan tercipta apabila penyelenggaraan pendidikan dapat dilaksanakan secara efektif dalam kerangka kerja yang konseptual. Efektifitas penyelenggaraan pendidikan akan menghasilkan mutu pendidikan yang diharapkan sesuai dengan visi, misi dan tujuan dari system pembelajaran yang diselenggarakan di lingkungan madrasah.

Salah satu usaha yang telah dilakukan madrasah untuk ikut serta dalam melestarikan lingkungan adalah dengan menerapkan program Adiwiyata. Sekolah adiwiyata adalah sekolah yang telah menerapkan system dengan maksud untuk mewujudkan warga sekolah yang bertanggung jawab dalam upaya perlindungan dan pengelolaam lingkungan hidup melalui tata sekolah yang baik untuk mendukung pembangunan berkelanjutan.

MAN adalah satu satunya madrasah Aliyah di Kabupaten Purworejo yang telah menerapkan program Adiwiyata adalah MAN Purworejo. Tahun 2019 bulan Agustus MAN Purworejo sudah berhasil menjadi madrasah Adiwiyata Tingkat Propinsi. Hubungannya dengan kualitas sekolah, madrasah juga menunjukkan peningkatan yang menggembirakan. Dalam bidang pengetahuan umum, dua tahun terakhir ini menunjukkan hasil yang menggembirakan. MAN berhasil memenangkan lomba OSN untuk bidang Matematika dan Biologi mewakili Kabupaten Purworejo untuk maju ke tingkat Propinsi.

Untuk mencapai tujuan adiwiyata madrasah harus mempersiapkan segala yang diperlukan untuk memenuhi standart Nasioal Pendidikan. Adapun persiapan dalam melaksanakan program antara lain membentuk komite lingkungan madrasah, mengakaji lingkungan sekitar madrasah dan mengembangkan rencana aksi. Persiapan madrasah dalam komponen Kebijakan berwawasan Lingkungan antara lain memuat program dalam upaya perlindungan dan pengeloaan Lingkungan hidup di dalam Rencana Kegiatan Anggaran Madrasah (RKAS). Adapun anggaran tersebut dialokasikan secara proporsional untuk kegiatan seperti kegiatan kesiswaan, kurikulum, peningkatan kapasitas pendidik dan tenaga kependidikan, sarana dan pra sarana, budaya dan lingkungan madrasah, peningkatan dan pengembangan mutu. 
Madrasah dalam merealisasikan kegiatan tersebut telah meleksanakan beberapa aksi antara lain merubah lingkungan madrasah menjadi lingkungan yang asri untuk mendukung pelestarian lingkungan hidup dengan menanam pohon pohon rindang di halaman madrasah. Selain itu madrasah juga merancang sarana kegiatan untuk mendukung pelaksanaan Adiwiyata, diantaranya penghematan listrik, air dan ATK, penggunaan biophori, pembangunan green house, penghijauan lingkungan sekitar , ruang terbuka hijau dan halaman sekolah untuk pembelajaran.

Berdasarkan uraian di atas, penulis mengkaji tentang Implementasi Konsep Madrasah Berwawasan Lingkungan (Studi Kasus di MAN Purworejo). Hal tersebut untuk mengetahui dan menganalisis tentang implementasi kebijakan berwawasan lingkungan, implementasi pelaksanaan kurikulum berbasis lingkungan, implementasi kegiatan lingkungan berbasis partisipatif, dan implementasi pengelolaan sarana pendukung ranah lingkungan dalam rangka meningkatkan mutu madrasah di MAN Purworejo.

\section{KAJIAN LITERATUR}

\section{Program Madrasah Adiwiyata}

Kata Adiwiyata berasal dari kata Sansekerta yaitu “Adi” bermakna: besar, agung, baik, sempurna. "Wiyata" bermakna: tempat di mana seseorang mendapat ilmu pengetahuan, norma. Jadi, Adiwiyata mempunyai pengertian atau makna: tempat yang baik dan ideal dimana dapat diperoleh segala ilmu pengetahuan dan berbagai norma serta etika yang dapat menjadi dasar manusia menuju terciptanya kesejahteraan hidup kita dan menuju cita-cita pembangunan berkelanjutan. Penelitian ini mendasarkan pada teori Adiwiyata menurut Rismawati. Adiwiyata dicanangkan untuk mendorong dan membentuk sekolah sekolah di Indonesia agar dapat turut melaksanakan upaya pemerintah menuju pelestarian lingkungan dan pembangunan berkelanjutan bagi kepentingan generasi sekarang maupun yang akan datang.

Adiwiyata sebagai sebuah program madrasah bertujuan menciptakan kondisi yang baik bagi madrasah untuk menjadi tempat pembelajaran dan tempat penyadaran warga madrasah baik pendidik, tenaga kependidikan, peserta didik maupun masyarakat sekitar madrasah, dalam upaya mendorong penyelamatan lingkungan dan pembangunan 
berkelanjutan (sustainable development) yang akhirnya dapat mewujudkan sekolah yang peduli dan berbudaya lingkungan. ${ }^{6}$

Selanjutnya Iswari dan Utomo, menjelaskan bahwa adiwiyata adalah program yang bertujuan untuk mewujudkan warga sekolah yang bertanggung jawab dalam upaya perlindungan dan pengelolaan lingkungan hidup. ${ }^{7}$

Untuk mencapai tujuan program Adiwiyata tersebut, maka ditetapkan empat komponen program yang menjadi satu kesatuan utuh dalam mencapai madrasah Adiwiyata, yaitu kebijakan berwawasan lingkungan, pelaksanaan kurikulum berbasis lingkungan, kegiatan lingkungan berbasis partisipatif, dan pengelolaan sarana pendukung ramah lingkungan. ${ }^{8}$

Program Adiwiyata merupakan program yang menyatu dalam 8 Standar Nasional Pendidikan sehingga pada proses pelaksanaannya tetap menjadi satu kesatuan yang utuh dan bulat sesuai dengan Peraturan Pemerintah Nomor 19 Tahun 2005 tentang Standar Nasional Pendidikan. Tujuan utama dari program adalah menumbuhkan budaya peduli lingkungan bagi warga madrasahkhususnya peserta didik. Untuk mencapai program tersebut dibutuhkan proses manajemen yang tertata dengan rapi.

\section{Manajemen Madrasah}

Manajemen adalah suatu proses dalam rangka mencapai tujuan dengan bekerja bersama melalui orang-orang dan sumber daya organisasi lainnya. Manajamen merupakan aktivitas kerja yang melibatkan koordinasi dan pengawasan terhadap pekerjaan orang lain, sehingga pekerjaan tersebut dapat diselesaikan secara efisien dan efektif. ${ }^{9}$

Manajemen sekolah pada dasarnya adalah prosedur atau proses pencapaian hasil tertentu dengan mendayagunakan sumber daya yang tersedia. Manajemen yang efektif bergantung pada kiprah sejumlah lembaga yang saling terkait. Menurut Eliyanto, manajemen sekolah/madrasah yaitu proses pemanfaatan seluruh sumber daya sekolah yang dilakukan melalui tindakan yang rasional dan sistematik (mencakup perencanaan,

\footnotetext{
6 Takarina Yusnidar. Peran Serta Warga Sekolah dalam Mewujudkan Program Adiwiyata di SMP Wilayah Semarang Barat. Journal of Educational Social Studies. Vol.4 No.1 Th. 2015, hlm.1-7.

${ }^{7}$ Rizky Dewi Iswari \& Suyud W. Utomo. Evaluasi Penerapan Program Adiwiyata untuk Membentuk Perilaku Peduli Lingkungan di Kalangan Siswa (Studi Kasus di SMA Neger 9 Tangerang Selatan dan MA Negeri 1 Serpong). Jurnal Ilmu Lingkungan. Vol.15 Issue 1. Th.2017, hlm. 35-41.

${ }^{8}$ Anonymous, 2013. http://www.un.org/en/events/sustainableenergyforall/. Diakses 16 Desember 2018.

${ }^{9}$ Robbins, Stephen P. and Mary coulter. Managemen (1 $11^{\text {th }} e d$ ). (New Jearsey: Prentice Hall, 2012), pg.7.
} 
pengorganisasian, pelaksanaan, dan pengendalian) untuk mencapai tujuan madrasah secara efektif dan efisien. ${ }^{10}$

Selanjutnya, menurut Nur, Harun, Ibrahim, manajemen madrasah dapat diartikan segala sesuatu yang berkenaan dengan pengelolaan proses pendidikan untuk mencapai tujuan yang telah ditetapkan baik tujuan jangka pendek, menengah, maupun tujuan jangka panjang. ${ }^{11}$

Berdasarkan pendapat di atas, dapat disimpulkan bahwa manajemen madrasah atau manajemen pendidikan adalah sebuah usaha bersama dari seluruh anggota organisasi pendidikan untuk mencapai tujuan pendidikan yang telah ditetapkan secara efektif dan efisien. Manajemen madrasah yang baik akan meningkatkan mutu pendidikan.

\section{Mutu Pendidikan}

Pengertian mutu (quality) menunjukkan sifat yang menggambarkan derajat "baik"nya suatu barang atau jasa yang diproduksi atau dipasok oleh suatu lembaga dengan kriteria tertentu. ${ }^{12}$ Mutu dapat juga diartikan sebagai gambaran dan karakteristik menyeluruh dari barang atau jasa yang menunjukkan kemampuannya dalam memuaskan kebutuhan yang diharapkan atau yang tersirat. Pengertian mutu dalam konteks pendidikan mengacu pada masukan, proses,luaran, dan dampaknya. ${ }^{13}$

Menurut B. Suryosubroto, mutu pendidikan dapat dilihat dari 2 hal, yakni yang mengacu pada proses pendidikan dan hasil pendidikan. Proses pendidikan yang bermutu terjadi apabila seluruh komponen pendidikan terlibat dalam proses pendidikan itu sendiri. Faktor-faktor dalam proses pendidikan adalah berbagai input seperti bahan ajar, metodologi, saran madrasah, dukungan administrasi, dan sarana prasarana dan sumber daya lainnya serta penciptaan suasana kondusif. Sedangkan mutu pendidikan dalam

\footnotetext{
${ }^{10}$ Eliyanto. Manajemen Sumber Daya Manusia (MSDM) Pendidikan. (Yogyakarta: Prodi MPI FITK UIN Sunan Kalijaga Yogyakarta, 2018), hlm.14.

${ }^{11}$ Nur, M, Harun CZ, \& Ibrahim S. Manajemen Sekolah dalam Meningkatkan Mutu Pendidikan pada SDN Dayah Guci Kabupaten Pidie. Jurnal Administrasi Pendidikan. Vol.4 No.1Th.2016, Aceh: PPs Unsyiah.

${ }^{12}$ Ridwan Abdullah Sani, Isda Pramuniati, \& Anies Mucktiany. Penjaminan Mutu Sekolah. (Jakarta: Bumi Aksara, 2015), hlm.3.

${ }^{13}$ Sudarwan Danim. Visi Baru Manajemen Sekolah, dari Unit Birokrasi ke Lembaga Akademik. (Jakarta: Bumi Aksara, 2006), hlm.53.
} 
konteks hasil pendidikan mengacu pada prestasi yang dicapai pada madrasah pada kurun waktu tertentu. ${ }^{14}$

Menurut Dzaujak Ahmad, mutu pendidikan adalah kemampuan madrasah dalam pengelolaan secara operasional dan efisien terhadap komponen komponen yang berkaitan dengan madrasah, sehingga menghasilkan nilai tambah terhadap komponen tersebut menurutnorma/ standart yang berlaku. ${ }^{15}$

Mutu pendidikan pada dasarnya terdiri atas berbagai indicator dan komponen yang saling berkaitan. Komponen dan variable yang menentukan terwujudnya mutu pendidikan yang baik secara umum masih dikaitkan dengan system, kurikulum, tenaga pendidik, peserta didik, proses belajar mengajar, anggaran, sarana prasarana pendidikan, lingkungan belajar,budaya organisasi, kepemimpinan dan sebagainya. Mutu pendidikan tidak diukur hanya berdasarkan hasil ujian atau tes peserta didik, karena memiliki rangkaian yang saling berhubungan mulai dari input, proses, output dan outcome. ${ }^{16}$

Peningkatan mutu madrasah menurut Karwati dan Priansa adalah suatu proses yang sistematis dan terus-menerus meningkatkan mutu proses belajar mengajar dan faktor-faktor yang berkaitan dengan itu, dengan tujuan agar menjadi target madrasah dapat dicapai dengan lebih efektif dan efisien. ${ }^{17}$

Berdasarkan pendapat tersebut, dapat disimpulkan mutu pendidikan adalah kualitas atau ukuran baik atau buruk proses pengubahan sikap dan tata laku seseorang atau sekelompok orang dalam usaha mendewasakan manusia untuk mendekatkan diri kepada Tuhan melalui upaya bimbingan pengajaran dan pelatihan. Mutu di bidang pendidikan meliputi mutu input, proses, output, dan outcome. Input pendidikan adalah segala sesuatu yang harus tersedia karena dibutuhkan untuk berlangsung proses. Input sumber daya meliputi sumber daya manusia (kepala madrasah, guru termasuk bimbingan konseling, pegawai, atau karyawan, siswa) dan sumber daya selebihnya (peralatan, perlengkapan, uang, bahan, dan sebagainya). Tinggi rendahnya mutu input

\footnotetext{
${ }^{14}$ Euis Karwati \& Donni Juni Priansa. Kinerja dan Profesionalisme Kepala Sekolah. (Bandung: Alfabeta, 2013), hlm.13.

${ }^{15}$ Sri Minarti. Manajemen Sekolah: Mengelola Lembaga Pendidikan secara Mandiri. (Yogyakarta: ArRuzz Media, 2012), hlm.328.

${ }^{16}$ Amtu, Onisimus. Manajemen pendidikan di Era Otonomi Daerah: Konsep, Strategi, dan Implementasi. (Bandung: Alfabeta, 2011), hlm.138.

${ }^{17}$ Euis Karwati \& Donni Juni Priansa, Op.Cit, hlm.59.
} 
dapat diukur dari tingkat kesiapan input. Makin tinggi tingkat kesiapan input, makin tinggi pula mutu input tersebut.

Peningkatan mutu madrasah adalah suatu proses yang sistematis yang terusmenerus mutu proses belajar mengajar dan factor-faktor yang berkaitan dengan itu, dengan tujuan agar menjadi target madrasah dapat dicapai lebih efektif dan efisien. Mutu pendidikan madrasah tertuju pada mutu lulusan yang berasal dari madrasah tersebut. Untuk menghasilkan lulusan yang bermutu, maka proses pendidikan harus bermutu juga.

\section{METODE PENELITIAN}

Jenis penelitian ini yaitu kualitatif pendekatan deskriptif, pendekatan yang lebih menekankan pada aspek pemahaman secara mendalam terhadap suatu masalah manusia dan sosial. Waktu penelitian adalah antara bulan Maret 2019 sampai dengan bulan Mei 2019, dan tempat penelitian adalah di MAN Purworejo. Lokasi MAN Purworejo ada di dua tempat, yaitu Jl. Kartini No. 17, Pangenjuru Tengah, Kec. Purworejo, Kab. Purworejo, Jawa Tengah dan Jl. Brigjen Katamso, Pangenrejo, RW 03, Kec. Purworejo, Kab. Purworejo, Jawa Tengah.

Subjek penelitian ini yaitu peneliti/penulis sendiri. Sedangkan responden penelitian ini yaitu kepala madrasah, wakil kepala madrasah, guru, dan pegawai tata usaha, dan siswa-siswi MAN Purworejo.

Teknik pengumpulan data merupakan cara yang digunakan peneliti untuk memperoleh data penelitian yang dibutuhkan. Proses pengumpulan data dalam penelitian ini dilakukan dengan: observasi, wawancara mendalam, dan dokumentasi.

Dalam menguji keabsahan data peneliti menggunakan tehnik Triangulasi, yakni teknik pemeriksaan keabsahan data yang memanfaatkan sesuatu yang lain diluar data untuk keperluan pengecekan atau sebagai pembanding terhadap data itu.Itu artinya melakukan validasi, dengan cara mengecek dokumen program dan bukti tertulis lainnya. ${ }^{18}$ Dalam penelitian ini menggunakan Triangulasi metode yaitu menggunakan dua strategi yaitu: (1) Pengecekan terhadap derajat kepercayaan penemuan hasil penelitian dengan beberapa tehnik pengumpulan data; (2) Pengecekan derajat kepercayaan beberapa sumber data dengan metode yang sama.

\footnotetext{
${ }^{18}$ Patton, Michael Quinn. Metode Evaluasi Kualitatif. (Yogyakarta: Pustaka Pelajar, 2006), hal. 280
} 
Langkah-langkah yang dilakukan penulis lakukan untuk menganalisis data yang sudah diperoleh dari hasil observasi, wawancara, dan dokumentasi yaitu dengan menggunakan model analisis data Miles dan Huberman sebagaimana yang dikutip oleh Sugiyono, yaitu reduksi data (data reduction), penyajian data (data display), dan penarikan kesimpulan (conclusion drawing/verification). ${ }^{19}$

\section{HASIL PENELITIAN DAN PEMBAHASAN}

\section{Implementasi Kebijakan Berwawasan Lingkungan di MAN Purworejo}

Salah satu standar program Adiwiyata adalah kebijakan berwawasan lingkungan. Kebijakan berwawasan lingkungan adalah perumusan suatu kebijakan sebagai pedoman yang menerapkan nilai-nilai peduli lingkungan.Arah dari kebijakan berwawasan lingkungan di sekolah sebagai pusat pemberdayaan niai-nilai pengelolaan lingkungan melalui lembaga pendidikan dan meningkatkan partisipasi warga sekolah, orang tua dan masyarakat dalam mengikuti kegiatan sekolah. Sebagaimana tercantum pada UU RI No 20 Tahun 2003 tentang Sistem Pendidikan Nasional, bahwa salah satu arah kebijakan pendidikan di Indonesia adalah memberdayakan lembaga pendidikan baik sekolah maupun luar sekolah sebagai pusat pembudayaan nilai, sikap, dan kemampuan, serta meningkatkan partisipasi keluarga dan masyarakat yang didukung oleh sarana dan prasarana yang memadai. ${ }^{20}$

Perumusan kebijakan berwawasan lingkungan di sekolah mengacu pada buku Pedoman Adiwiyata mengenai komponen dan standar kebijakan berwawasan lingkungan. Kebijakan dirumuskan oleh Tim Adiwiyata dengan dibantu oleh Kepala Sekolah. Pada tahap awal disusun rencana kegiatan yang akan dilaksanakan selama satu tahun. Kegiatan tersebut berkaitan dengan penentuan kebijakan sekolah yang berwawasan lingkungan dengan meliputi visi dan misi tujuan sekolah, struktur kurikulum yang memuat tentang nilai-nilai lingkungan, sosialisasi program Adiwiyata, inventarisasi sarana dan prasarana berwawasan lingkungan dan penyusunan jadwal aksi lingkungan. Setelah kebijakan selesai dirumuskan, kemudian disosialisasikan pada saat upacara, kegiatan MOS sekolah, dan berbagai kegiatan sekolah.

\footnotetext{
${ }^{19}$ Sugiyono, Metode Penelitian Pendidikan, (Bandung: Alfabeta. 2009), hal. 254

${ }^{20}$ Undang-undang Republik Indonesia Nomor 20 Tahun 2003 tentang Sistem Pendidikan Nasional.
} 
Untuk mewujudkan sekolah yang peduli dan berbudaya lingkungan maka diperlukan beberapa kebijakan sekolah yang mendukung dilaksanakannya kegiatan kegiatan pendidikan lingkungan hidup oleh semua warga sekolah sesuai dengan prinsip prinsip dasar program Adiwiyata yaitu partisipatif dan berkelanjutan.

Pengembangan kebijakan sekolah tersebut antara lain visi dan misi sekolah yang peduli dan berbudaya lingkungan. Visi misi yang sudah ada dirubah disesuaikan dengan sekolah yang peduli lingkungan dan mengembangkan pembelajaran pendidikan lingkungan hidup. Hal tersebut sudah diterapkan di MAN Purworejo dengan mengimplementasikan kurikulum berwawasan lingkungan. Implementasi kurikulum berwawasan lingkungan dilaksanakan secara integralistik. Artinya setiap mata pelajaran dikaitkan dengan pembelajaran lingkungan hidup. Setiap RPP pada bagian pendahuluan dan kegiatan pembelajaran dihubungan dengan lingkungan.

Keberhasilan implementasi suatu kebijakan dipengaruhi oleh beberapa faktor. Arif Rohman mengatakan bahwa ada tiga faktor yang menentukan kegagalan dan keberhasilan dalam implementasi kebijakan, yaitu: perumus kebijakan, personil pelaksana dan sistem organisasi pelaksana. ${ }^{21}$ Kebijakan berwawasan lingkungan telah dirumuskan oleh Tim Adiwiyata dengan bantuan kepala sekolah. Apabila sebuah kebijakan sudah mendapatkan persetujuan dari kepala sekolah maka kebijakan mengenai wawasan lingkungan tersebut akan menjadi sebuah peraturan baru yang harus dipatuhi oleh peserta didik, guru, dan karyawan sekolah. Visi, misi, peraturan dan tata tertib yang berwawasan lingkungan merupakan bentuk dari komitmen dari segenap warga sekolah, mulai dari kepala sekolah, guru, siswa sampai karyawan untuk senantiasa menyelaraskan kegiatan di sekolah baik dalam pembelajaran maupun ekstrakurikuler dengan menumbuhkan kesadaran dan kepedulian terhadap lingkungan. Komitmen seluruh warga sekolah akan menjadi tolok ukur dalam melakukan tindakan, sehingga apa yang haus dilakukan oleh seluruh warga sekolah dalam berpartisipasi diprogram Adiwiyata menjadi lebih jelas dan terarah menuju tujuan program Adiwiyata.

Visi dan misi MAN Purworejo telah memuat upaya perlindungan lingkungan.Visi dan misi disosialisasikan kepada seluruh warga sekolah terutama saat Masa Orientasi Siswa. Akan tetapi saat ditanya peserta didik ada yang kurang faham tentang visi misi sekolah yang berbudaya lingkungan. Hal ini berarti masih ada warga sekolah yang

\footnotetext{
${ }^{21}$ Arif Rohman. Politik Ideologi Pendidikan. (Yogyakarta: Mediatama, 2009), hlm.147.
} 
belum memahami tentang Adiwiyata. Akan tetapi dalam praktik sehari hari peserta didik sudah melaksanakan program tentang kepedulian lingkungan.

Terkait dengan visi dan misi sekolah, Sekolah harus mensosialisasikan visi dan misinya kepada seluruh SDM yang ada di sekolah. Sosialisasi dapat dilakukan dalam berbagai kegiatan yang diselenggarakan oleh sekolah. Untuk dapat dipahami secara mendalam oleh seluruh komponen sekolah, visi dan misi dapat dibuat menjadi poster yang menarik dan ditempel pada berbagai ruang dan tempat tempat sekolah yang strategis. ${ }^{22}$ Dalam prakteknya madrasah telah memasang tulisan visi misi tersebut di halaman depan pintu masuk ke MAN Purworejo dan dipasang di setiap ruang kelas dengan harapan dapat dipahami oleh seluruh warga sekolah.

Salah satu program Madrasah adalah kepedulian lingkungan yaitu mensosialisasikan kepedulian lingkungan bagi seluruh warga sekolah bahkan tamu yang berkunjung untuk tidak merokok. Dalam implementasinya, sosialisasi ini sudah terlaksana bagi warga sekolah namun terkadang masih saja ada pelanggaran dan kontrol yang kurang maksimal dari pihak sekolah seperti masih terdapat tamu yang merokok di sekitar lingkungan sekolah.

\section{Implementasi Pelaksanaan Kurikulum Berbasis Lingkungan di MAN Purworejo}

Kurikulum berbasis lingkungan adalah kurikulum yang memuat tentang matei pengelolaan dan perlindungan terhadap lingkungan hidup yang disampaipaikan dengan beragam cara dalam upaya memberikan pemahaman tentang lingkungan hidup. Hal tersebut seperti yang diungkapkan oleh Ahmad Fajarisma, bahwa kurikulum berbasis lingkungan secara sederhana dapat diimplementasikan dengan cara penyampaian materi lingkungan hidup melalui kurikulun yang beragam variasi untuk memberikan pemahaman tentang lingkungan hidup yang dikaitkan dalam kehidupan sehari-hari. Kurikulum tersebut diselenggarakan untuk meningkatkan kesadaran warga sekolah mengenai pendidikan lingkungan. ${ }^{23}$ Pendidikan lingkungan memainkan peranan yang penting sebagai pembentuk dan penyebar nilai-nilai cinta lingkungan, sehingga tercapai keselarasan dengan lingkungan.

\footnotetext{
${ }^{22}$ Muhaimin. Pengembangan Kurikulum PAI di Sekolah, Madrasah, dan Perguruan Tinggi. (Jakarta: Rajawali Pers, 2009), hlm.156.

23 Ahmad Fajarisma. Analisis Implementasi Kebijakan Kurikulum berbasis Lingkungan Hidup di SDN Diniyo 2 Malang, Jurnal Kebijakan dan Pengembangan Pendidikan, Vol. 2, No. 2 (Juli 2014): 166-173.
} 
Maftuchah Yusuf mengatakan bahwa salah satu tujuan pokok yang hendak dicapai dalam pendidikan lingkungan hidup adalah membantu anak didik memahami lingkungan dengan tujuan akhir agar mereka memiliki kepedulian dalam menjaga dan melestarikan lingkungan hidup. ${ }^{24}$

Standar pertama yaitu terkait dengan kurikulum tingkat satuan pendidikan yang memuat upaya perlindungan hidup. Secara keseluruhan, MAN Purworejo telah melaksanakan sesuai dengan standar komponen Adiwiyata yaitu perumusan visi dan misi yang memuat perlindungan hidup, Struktur kurikulum memuat muatan lokal, pengembangan diri terkait kebijakan perlindungan dan pengelolaan lingkungan hidup dan ekstra Pendidikan Lingkungan Hidup sudah ada, namun Kurikulum tingkat Satuan Pendidikan yang berisi tentang Adiwiyata belum ada.

Dalam proses pembelajaran lingkungan hidup, pihak sekolah sudah berusaha untuk melibatkan orang tua siswa terutama ketika pengambilan raport orang tua dilibatkan untuk kerja bakti bersama dan membawa bibit pohon pohonan untuk ditanam di sekolah. Siswa ikut berpartisipasi dalam kebersihan kelas, lomba lomba yang berkaitan dengan lingkungan hidup seperti lomba dalam rangka hari Kartini, lomba pemilihan duta Adiwiyata. Sedangkan yang berkaitan dengan cinta lingkungan sekolah mengikutsertakan kegiatan kegiatan yang diadakan oleh pihak luar, mengikuti worshop tentang lingkungan hidup, serta mengikutsertakan lomba yang berkaitan dengan lingkungan hidup, seperti membuat puisi, cerita dan lain lain.

Upaya upaya sekolah dalam mengembangkan kurikulum berbasis Lingkungan diantaranya diadakannya ekstra Pendidikan Lingkungan Hidup, studi banding ke SMA N I Prembun sebagai sekolah Adiwiyata Tingkat Nasional. Tujuan Pendidikan Lingkungan Hidup di MAN Purworejo adalah agar siswa memiliki pengetahuan, sikap dan perilaku rasional dan bertanggungjawab terhadap masalah kependudukan dan lingkungan hidup.

Pendidikan lingkungan hidup diharapkan menjadi salah satu sumber belajar dengan memiliki pengetahuan,keterampilan, sikap dan perilaku, motivasi serta komitmen untuk memecahkan berbagai masalah lingkungan dan mencgah timbulnya masalah kerusakan lingkungan.

\footnotetext{
${ }^{24}$ Syukri Hamzah, Op.Cit, hlm.49.
} 
Pendidikan lingkungan hidup bukan mata pelajaran yang berdiri sendiri melainkan mata pelajaran yang diintegrasikan ke berbagai mata melajaran dalam kurikulum, diantaranya Pendidikan Agama, Bahasa Indonesia, IPA, IPS, Matematika dan Pendidikan Kewarganegaraan. Hal ini sudah dilaksanakan di Madrasah. Materi berwawasan lingkungan yang diintegrasikan baik dalam pembelajaran didalam kelas merupakan salah satu upaya membentuk kepribadian cinta terhadapa lingkungan. Walaupun sudah tertulis dalam RPP, alangkah lebih baik guru juga menjadi contoh dalam mengelola lingkungan sekolah.

Proses pembelajaran lingkungan hidup di MAN Purworejo tidak hanya sebatas teori saja, tetapi dalam praktik pengelolaan lingkungan juga diajarkan seperti pengelolaan sampah, memanfaatkan daur ulang limbah, cara membuat kompos, menanam pohon, pembenihan dan lain sebagainya. Dengan pengalaman langsung peserta didik diharapkan akan memiliki kemampuan untuk melakukan pengelolaan lingkungan. Dengan demikian dapat disimpulkan bahwa pelaksanaan kurikulum berwawasan lingkungan di MAN Purworejo telah sesuai dengan standar Adiwiyata.

\section{Implementasi Kegiatan Lingkungan Berbasis Partisipatif di MAN Purworejo}

Kegiatan lingkungan berbasis partisipasif adalah kegiatan yang melibatkan warga sekolah dan masyarakat di sekitarnya dalam melakukan berbagai kegiatan yang memberikan manfaat baik bagi warga sekolah, masyarakat maupun lingkungannya dalam rangka kegiatan pengelolaan lingkungan hidup. Pelaksanaan kegiatan lingkungan bersifat partisipasif di sekolah diintegrasikan dalam kegiatan pembiasaan dan ekstrakurikuler.

Kegiatan lingkungan bersifat partisipasif dilaksanakan sesuai dengan standar sekolah Adiwiyata yang telah ditentukan oleh Kementerian Lingkungan Hidup dan Kementerian Pendidikan. Indikator keberhasilan pencapaian program kegiatan lingkungan berbasis partisipatif dilihat pada dua standar yaitu pertama, melaksanakan kegiatan perlindungan dan pengelolaan lingkungan hidup yang terencana bagi warga sekolah. Kedua, menjalin kemitraan dalam rangka perlindungan dan pengelolaan lingkungan hidup dengan berbagai pihak (masyarakat, pemerintah, swasta, media, sekolah lain). 
Kegiatan lingkungan bersifat partisipasif dilaksanakan sesuai dengan standar sekolah Adiwiyata yang telah ditentukan oleh Kementerian Lingkungan Hidup dan Kementerian Pendidikan. Madrasah telah melaksanakan kegiatan perlindungan dan pengelolaan lingkungan hidup yang terencana bagi warga sekolah secara keseluruhan yang meliputi pemeliharaan lingkungan bersama seperti piket kebersihan kelas, Sabtu bersih, pemeliharaan taman. Namun sering kali yang menjadi kendala adalah kesadaran peserta didik terhadap lingkungan yang masih bersifat fluktuatif.

Kemudian standar yang kedua adalah memanfaatkan lahan dan fasilitas sesuai kaidah-kaidah lingkungan hidup melalui: pembuatan kolam, Green House, taman dan pembuatan kompos. Kriteria yang ketiga adalah adanya kreatifitas dan inovasi warga sekolah dalam upaya perlindungan dan pengelolaan lingkungan hidup melalui: pembuatan pupuk kompos, pengelolaan sanitasi, publikasi karya ilmiah, pemanfaatan daur ulang limbah.

Untuk mengembangkan karakter cinta lingkungan, MAN Purworejo telah mengembangkan kegiatan ekstrakurikuler yang sesuai denga upaya perlindungan dan pengelolaan lingkungan hidup. Menurut Tim Dosen AP UPI, kegiatan ekstrakurikuler adalah semua kegiatan yang telah ditentukan di dalam kurikulum yang pelaksanaannya dilakukan pada luar jam-jam pelajaran.kegiatan ekstrakurikuler di sekolah dibagi dalam jadwal diluar pembelajaran. ${ }^{25}$ Hal tersebut menghindari agar tidak terjadi masalah dalam penggunaan sarana pendukung. Pengembangan ekstrakurikuler tersebut lebih mengarah kepada pembinaan potensi peserta didik dan pembiasaan cinta lingkungan.

Kegiatan lingkungan berbasis partisipatif di MAN Purworejo juga dilaksanakan dengan jalur kemitraan. Sekolah dalam upaya meningkatkan pengelolaan lingkungan hidup mendapatkan dukungan berbagai pihak seperti SMK N I Purworejo, Dinas Lingkungan Hidup, Muslimat, NU, Puskesmas, Bank Sampah Induk, Kelurahan Pangen Juru Tengah, Alumni MAN/ Palmanep, PLN, PDAM dan masyarakat sekitar. Selain itu, kemitraan pihak antara sekolah dan komite sudah sangat terjalin dengan baik di MAN Purworejo. Hal ini telah sesuai dengan apa yang tertuang dalam buku pedoman Adiwiyata yang mensyaratkan 3 (tiga) kemitraan yang difasilitasi oleh komite sekolah

25 Tim Dosen Jurusan Administrasi Pendidikan UPI. Pengelolaan Pendidikan. (Bandung: Jurusan Administrasi Pendidikan, 2013), hlm.212. 
terkait dengan pembelajaran lingkungan hidup dan upaya perlindungan dan pengelolaan lingkungan hidup. ${ }^{26}$

Peran humas sangat penting karena humas sekolah sangat menentukan program Adiwiyata. Humas memiliki tugas untuk menjembatani pihak sekolah dengan pihak luar karena humas sebagai jembatan informasi yang menghubungkan agar tercapainya sebuah program. Dengan adanya dukungan dari berbagai pihak, sekolah dapat menjalin kerjasama yang saling menguntungkuan. Hal tersebut sebagaimana yang diungkapkan oleh Suryosubroto, bahwa hubungan masyarakat dilakukan dengan tujuan memperoleh keuntungan dan kemudahan bagi kedua belah pihak. ${ }^{27}$

Teknik yang digunakan humas sekolah untuk memperoleh dukungan yaitu dengan melalui media sosial, informasi tertulis yang berbentuk papan nama, rapat bersama dan mengadakan promosi sekolah. Metode rapat bersama dilakukan dengan cara mengundang beberapa instansi ketika mengadakan rapat perencanaan kegiatan Adiwiyata. Metode promosi dilakukan dengan cara mengikuti acara yang diselenggarakan pihak luar, seperti karnaval HUT 17 Agustus dan kegiatan-kegiatan aksi lingkungan seperti bersih-bersih saat Bakti Sosial di Wonoroto, Bersih lingkungkungan di sekitar rumah sakit DKT, serta Pungut Sampah di sekitar Alun Alun Purworejo.

Adapun kendala yang ditemui dalam kegiatan lingkungan berbasis partisipasif. Masalah yang ditemui adalah masih kurangnya kesadaran guru dan kurangnya kerjasama dalam mengikuti kegiatan. Beberapa Guru masih memiliki pola pikir bahwa setiap warga sekolah sudah memiliki tugas sendiri, sehingga tidak perlu campur tangan. Kurangnya kerjasama ini dapat menimbulkan hambatan dalam pelaksanaan kegiatan aksi lingkungan. Solusi yang diterapkan oleh humas sekolah adalah bekerja sama dengan tim Adiwiyata yaitu secara rutin mensosialisasikan aksi lingkungan kepada seluruh warga sekolah

Indikator lain dalam pencapaian kegiatan lingkungan Adiwiyata menyebutkan bahwa warga sekolah setidaknya pernah menjadi narasumber dalam pembelajaran lingkungan hidup. Indikator tersebut belum terlaksana maksimal di MAN Purworejo karena selama ini warga sekolah lebih banyak bertindak sebagai partisipan kegiatan

\footnotetext{
${ }^{26}$ Anonymous, Op.Cit, hlm.26.

${ }^{27}$ Suryosubroto. Manajemen Pendidikan di Sekolah. (Jakarta: Rineka Cipta, 2004), hlm.1.
} 
lingkungan bukan sebagai narasumber. Hanya ada beberapa guru saja yang pernah menjadi narasumber untuk pendidikan lingkungan hidup di sekolah lain. Karena dalam standar pencapaian Adiwiyata membebankan minimal 3 kali warga sekolah menjadi narasumber dalam acara lingkungan hidup seperti sekolah lain, seminar, dan pemerintah daerah.

\section{Implementasi Pengelolaan Sarana Pendukung Ranah Lingkungan dalam Rangka Meningkatkan Mutu Madrasah di MAN Purworejo}

MAN Purworejo dalam rangka mendukung program Adiwiyata telah menyediakan sarana ramah lingkungan. Pengelolaan sarana pendukung diproyeksikan pada pengelolaan sumber daya secara efektif dan efisien. Pengelolaan sarana pendukung dilaksanakan melalui beberapa program yaitu Pengelolaan tempat sampah, Pengelolaan Green house,kolam ikan, dan kebun, Pemeliharaan sanitasi sekolah, pemeliharaan kebersihan kamar mandi, Pengelolaan pelayanan kantin sekolah, Pengelolaan air, listrik, dan ATK secara efisien.

Penyediaan sarana prasarana di MAN Purworejo untuk mengatasi permasalahan lingkungan hidup di sekolah sesuai dengan standar sarana dan prasarana Permendiknas No. 24 tahun 2007, seperti: air bersih, sampah (penyediaan tempat sampah terpisah, komposter), tinja, air limbah/drainase, ruang terbuka hijau, kebisingan/getaran/radiasi.

Pemanfaatan sarana ramah lingkungan di madrasah adalah penggunaan Green House toga dan ruang terbuka hijau untuk praktikum biologi, halaman sekolah sebagai sarana pembelajaran peserta didik. Madrasah telah membuat sarana prasarana pendukung pembelajaran lingkungan hidup, antara lain; pengomposan, pemanfaatan dan pengolahan air, taman/kebun sekolah, green house, toga, kolam ikan, biopori, sumur resapan. Namun untuk biopori yang ada belum berfungsi secara maksimal dikarenakan debit air terlalu banyak. Namun kendala seperti ini masih dapat diatasi dengan adanya sumur resapan dan juga saluran air (selokan).

Kantin madrasah sudah tidak menjual makanan yang berbahan pengawet/pengenyal/ pewarna yang tidak sesuai standar kesehatan. Namun, kantin sekolah masih menggunakan bungkus makanan yang terbuat dari bahan sintetis seperti plastik, terutama untuk makanan yang tidak berasal dari kantin madrasah. Hal ini masih belum sesuai dengan standar yang sudah ditetapkan tim Adiwiyata Nasional yaitu untuk kantin tidak menjual makanan yang dikemas tidak ramah lingkungan, seperti plastic, 
styrofoam, aluminium foil. ${ }^{28}$ Karena kantin sekolah memiliki manfaat yang besar dari aspek edukatif dan aspek kesehatan. Kantin sekolah seharusnya menjual makanan dan minuman yang sehat dan halal. Di tembok kantin sebaiknya dihiasi berbagai gambar makanan, buah-buahan, sayur-sayuran, termasuk jenis makanan yang memenuhi standar kesehatan. Bahkan akan lebih bagus kalau ada poster tentang doa sebelum makan untuk mengingatkan peserta didik supaya selalu berdo'a baik sebelum maupun sesudah makan. Dapat disimpulkan bahwa pengelolaan sarana dan prasarana lingkungan hidup dengan cara menyediakan fasilitas ramah lingkungan, meningkatkan kualitas fasilitas, efisiensi penggunaan listrik, air dan pengelolaan sampah sekolah.

\section{KESIMPULAN}

Berdasarkan penelitian dan pembahasan yang telah diuraikan tentang Pelaksanaan sekolah Adiwiyata di MAN Purworejo dapat diambil kesimpulan bahwa:

1. Pelaksanaan Kebijakan berwawasan lingkungan, madrasah telah merubah visi misi yang berwawasan lingkungan hidup, mengalokasikan dana sebesar $20 \%$ setelah dikurangi gaji dan tunjangan dari total anggaran madrasah guna pengelolaan program adiwiyata di MAN Purworejo

2. Kurikulum berbasis lingkungan dilaksanakan secara integratik (integrated curriculum) maksudnya materi tentang kepedulian lingkungan selalu disisipkan dalam setiap mata pelajaran maupun kegiatan ekstrakurikuler

3. Kegiatan lingkungan berbasis partisipatif di laksanakan melalui kegiatan aksi lingkungan baik yang disenggarakan oleh sekolah maupun yang diselenggarakan oleh pihak luar.

4. Pengelolaan sarana pendukung ramah lingkungan, diadakannya program pengelolaan sampah, penghematan penggunaan listrik, air, dan ATK, pengelolaan layanan kantin sekolah dan memanfaatkan sarana Green House, ruang terbuka hijau dan halaman sekolah untuk pembelajaran, terutama untuk praktikum Biologi.

\footnotetext{
${ }^{28}$ Anonymous, Op.Cit, hlm.27.
} 


\section{DAFTAR PUSTAKA}

Ahmad Fajarisma. (2014). Analisis Implementasi Kebijakan Kurikulum berbasis Lingkungan Hidup di SDN Diniyo 2 Malang, Jurnal Kebijakan dan Pengembangan Pendidikan, Vol. 2, No. 2 (Juli 2014): 166-173.

Amtu, Onisimus.(2011). Manajemen pendidikan di Era Otonomi Daerah: Konsep, Strategi, dan Implementasi. Bandung: Alfabeta.

Anonymous, 2013. http://www.un.org/en/events/sustainableenergyforall/. Diakses 16 Desember 2018.

Arif Rohman. (2009). Politik Ideologi Pendidikan. Yogyakarta: Mediatama.

Eliyanto. (2018). Manajemen Sumber Daya Manusia (MSDM) Pendidikan. Yogyakarta: Prodi MPI FITK UIN Sunan Kalijaga Yogyakarta.

Euis Karwati \& Donni Juni Priansa. (2013). Kinerja dan Profesionalisme Kepala Sekolah. Bandung: Alfabeta.

Hamzah, Syukri Hamzah. (2013). Pendidikan Lingkungan: Sekelumit Wawasan Pengantar. Bandung: Refika Aditama.

Muhaimin. (2009). Pengembangan Kurikulum PAI di Sekolah, Madrasah, dan Perguruan Tinggi. Jakarta: Rajawali Pers.

Nur, M, Harun CZ, \& Ibrahim S. (2016). Manajemen Sekolah dalam Meningkatkan Mutu Pendidikan pada SDN Dayah Guci Kabupaten Pidie. Jurnal Administrasi Pendidikan. Vol.4 No.1 Aceh: PPs Unsyiah.

Patton, Michael Quinn. (2006). Metode Evaluasi Kualitatif. Yogyakarta: Pustaka Pelajar.

Peraturan Menteri Negara Lingkungan Hidup Republik Indonesia Nomor 15 Tahun 2012 tentang Panduan Valuasi Ekonomi Ekosistem Hutan.

Ridwan Abdullah Sani, Isda Pramuniati, \& Anies Mucktiany. (2015). Penjaminan Mutu Sekolah. Jakarta: Bumi Aksara.

Rizky Dewi Iswari \& Suyud W. Utomo. (2017). Evaluasi Penerapan Program Adiwiyata untuk Membentuk Perilaku Peduli Lingkungan di Kalangan Siswa (Studi Kasus di SMA Neger 9 Tangerang Selatan dan MA Negeri 1 Serpong). Jurnal Ilmu Lingkungan. Vol.15 Issue 1. Hlm. 35-41.

Robbins, Stephen P. and Mary coulter. 2012. Managemen $\left(11^{\text {th }}\right.$ ed). New Jearsey: Prentice Hall.

Rohiat. (2008). Manajemen Sekolah: Teori Dasar dan Praktik, Dilengkapi dengan Contoh Rencana Strategis dan Rencana Operasional. Bandung: Refika Aditama. 
Jurnal Cakrawala: Studi Manajemen Pendidikan Islam dan Studi Sosial Vol.4 No.1 Th 2020 P-ISSN: 2580-9385, E-ISSN: 2581-0197

http:// ejournal.iainu-kebumen.ac.id/ index.php/ cka/index

Sri Minarti. (2011). Manajemen Sekolah: Mengelola Lembaga Pendidikan secara Mandiri. Yogyakarta: Ar-Ruzz Media.

Sudarwan Danim. (2006). Visi Baru Manajemen Sekolah, dari Unit Birokrasi ke Lembaga Akademik. Jakarta: Bumi Aksara.

Sugiyono. (2009). Metode Penelitian Pendidikan. Bandung: Alfabeta.

Suryosubroto. (2004). Manajemen Pendidikan di Sekolah. Jakarta: Rineka Cipta.

Takarina Yusnidar. (2015). Peran Serta Warga Sekolah dalam Mewujudkan Program Adiwiyata di SMP Wilayah Semarang Barat. Journal of Educational Social Studies. Vol.4 No.1 Hlm.1-7.

Tim Dosen Jurusan Administrasi Pendidikan UPI. (2013). Pengelolaan Pendidikan. Bandung: Jurusan Administrasi Pendidikan.

Undang-undang Republik Indonesia Nomor 20 Tahun 2003 tentang Sistem Pendidikan Nasional.

Undang Undang Republik Indonesia Nomor 32 Tahun 2009 tentang Perlindungan dan Pengeloaan Lingkungan Hidup (PPLH). 